\title{
Factors Influencing Charity Shop Customers' Intention to Use Online Charity Shops
}

Hayır Mağazası Müşterilerinin Online Satın Alma Niyetlerini Etkileyen

Faktörler

\author{
Samet Can CURKAN*
}

Özge CURKAN ${ }^{* *}$

\begin{abstract}
With the rise of e-commerce in recent years, many charities have started selling online mainly through their online shop or their eBay shop. This paper aims to understand the factors that determine charity shop customers' intention to use online charity shops by adopting the Unified Theory of Acceptance and Use of Technology 2 (UTAUT2). Furthermore, the study aims to identify current and future online charity shop customers in terms of their demographic characteristics particularly age and gender, and their experience with charity shops. The results revealed that performance expectancy significantly affects charity shop customers' intention to use online charity shops. Charity shop customers believe that online charity shops are useful in their daily life and increases their productivity in accomplishing shopping tasks more quickly.
\end{abstract}

Keywords: UTAUT2, online charity shops, behavioural intention, charity shop customers

$\ddot{\mathrm{O} z}$

Elektronik ticaretin önem kazandığı son yıllarda, birçok yardım kuruluşu da kendi online alışveriş sitesi veya eBay mağazası başta olmak üzere internet aracılığıyla satış yapmaya başlamıştır. Bu çalışma, Birleştirilmiş Teknoloji Kabul ve Kullanımı Teorisi 2 (BTKKT2) ile yardım kuruluşlarına bağlı hayır mağazalarından alışveriş yapan müşterilerin online alışveriş yapma niyetlerini belirleyen faktörleri araştırmaktadır. Ayrıca, bu çalışmayla mevcut ve potansiyel online hayır mağazası müşterilerinin yaş ve cinsiyet gibi demografik özellikleriyle birlikte hayır mağazalarından ne sıklıkta alışveriş yaptıkları da belirlenmiştir. Sonuçlar genel olarak performans beklentisi faktörünün, hayır mağazaları müşterilerinin online hayır mağazalarını kullanım niyetini doğrudan etkilediğini göstermektedir. Aynı zamanda hayır mağazası müşterileri online hayır mağazalarını kullanmanın alışveriş yaparken verimliliği artırdığını ve alışveriş eylemini daha hızlı hale getirdiğini düşünmektedir.

Anahtar kelimeler: BTKKT2, online hayır mağazaları, davranışsal niyet, hayır mağazası müşterileri

\section{Introduction}

Charity shops appeared as a retailing phenomenon in the UK in the 1980s and 1990s (Horne \& Maddrell, 2002). They sell mostly second-hand donated items to provide funds to their parent charities, and charity retail contributed over $£ 270$ million to charitable causes in 2016 (Charity Retail Association, 2017). According to the research conducted by Mintel (2017), the most common way to give to charities is by shopping at charity shops (35\%). In this regard, charity shops can be deemed the lifeblood of charitable organisations in the UK as they have a crucial role in the fundraising efforts of charities. Therefore, it is worth studying charity shops from a marketing perspective to help charities to improve their fundraising performance for the sake of their charitable purposes.

In traditional marketing, charity shopping is associated with economic benefits as charity shoppers assumed as deal-prone consumers (Bardhi, 2003). However, besides the price advantage, a growing number of people use charity shops for various reasons such as support for the charity, the environmental and ethical benefits, the need or desire for the range of items available, and personal interest in retro and vintage clothing (Charity Retail

\footnotetext{
* Arş. Gör. Ege Üniversitesi, Çeşme Turizm ve Otelcilik Yüksekokulu, Seyahat İşletmeciliği Bölümü, samet.can.curkan@ege.edu.tr.

*** Doktora Öğrencisi, Middlesex University London, Dicipline of Bussiness, ozcurkan@ hotmail.com.
}

Curkan, S. C. \& Curkan, Ö. (2019). Factors Influencing Charity Shop Customers' Intention to Use Online Charity Shops, Gaziantep University Journal of Social Sciences, 18(2), 597-622, Submission Date: 18-03-2019, Acceptance Date: 14-03-2019.

Araştırma Makalesi. 
Association, 2015). As charity shopping provides pleasure benefits as well as economic benefits (Bardhi, 2003), charity shops welcome a wide range of charity shoppers with diverse needs and tastes. Accordingly, it is very important for charities to understand their customers and meet their needs to be able to boost their retail sales.

As technology advances, it brings many changes to every aspect of consumers' lives which results in the shift in consumer behaviour that marketers need to pay attention to. Consumers have moved towards online shopping in recent years, and as a result the retail industry has undergone a huge shift towards e-commerce. As most businesses have started selling online, they have become more concerned about the purchase intention and behaviour of online shoppers to accommodate themselves to the online marketplace. The internet presents opportunities not only for for-profit organisations, but also for non-profit organisations. Therefore, besides their high street shops, most charities have also started selling through different online platforms. Oxfam, for example, has its own online shop, and also sells on eBay, Amazon and other sites, and both British Heart Foundation and Sue Ryder have their own eBay shop as well as online shop (Seager, 2014). As a result, charities are now expected to tailor online retail strategies to the tastes and preferences of their customers.

\section{Literature Review}

Charity shop is a non-profit retail phenomenon viewed as a prominent feature of high streets throughout the UK (Horne, 2000; Parsons, 2002). Many charity shops sell only donated goods such as men's, women's and children's clothing, books, toys, kitchenware, DVDs, music, computer games, furnishings and bric-a-brac, whereas others sell both donated items and bought-in goods which are new goods being sold for profit (Charity Retail Association, 2015). The numbers of charity shops in the UK increased significantly throughout the 1990s (Parsons, 2002), and there are currently over 10,000 charity shops across the UK, raising more than $£ 270$ million for charitable causes every year (Charity Retail Association, 2017).

As charity shop numbers have increased, charities have adopted a commercial sales approach by introducing bought-in (new) goods in their shops, which, in turn, has substantially broadened their customer base (Parsons, 2000). As a result, charity shops welcome a wide range of charity shoppers from various backgrounds which drives charities to improve their retail practices. Apart from the fact that traditional retail strategies are very important for charities to survive on the high streets, it is also essential for them to develop online retail strategies for their online shops since many charities have started selling online as a result of the shift in consumer behaviour towards online channels. This, in turn, brings up the issue of charity shop customers' adoption of online charity shops and their intention to use. The present study, therefore, draws attention to the importance of understanding charity shop customers from a marketing perspective within the context of online charity shopping.

\section{Charity Shop Customers}

Charity shop customers, or charity shoppers, will be defined by the researcher of this study since no definition has been encountered in the literature. Charity shop customers can be basically defined as people who purchase donated or bought-in goods from a charity shop mainly for economic and pleasure benefits. As mentioned earlier, focusing on the economic aspect of charity shopping is deemed outdated since there are also charity shoppers who seek pleasure benefits. Donated goods refer to both second-hand and brand-new items, while bought-in goods refer to new merchandise. Charity shop donors who only donate to the charities are not within the scope of this study as they cannot be considered as customers unless they make purchase. This study, therefore, covers solely charity shop customers who shop at charity shops across the UK, regardless of the benefits they seek. 
Charity shops are popular with a wide range of customers from diverse backgrounds (Parsons, 2000). Therefore, it is necessary for charities to understand their customers with different needs and wants to be able to develop successful retail strategies. However, charity shop customers have been neglected in the literature. There are only few studies on charity shop customers exploring the age and gender differences in charity shopping behaviour (Parsons, 2000; Mitchell \& Montgomery, 2010; Montgomery \& Mitchell, 2014). In brief, more women shop at a charity shop than men, and charity shopping is more popular with elderly people than young people. Likewise, the report produced by Charities Aid Foundation (CAF) (2016) shows that women are more likely to have ever purchased an item from a charity shop than men (90\% vs. 82\%), and older people are more likely to have bought an item in a charity shop than average ( $71 \%$ of $65+$ year olds versus $63 \%$ overall).

Overall, as charity shop customers have not received adequate attention in the existing literature, more research needs to be done in different contexts. The present study, therefore, focus on charity shop customers in the context of online charity shopping, regardless of their past experience with online charity shops.

\section{Online Charity Shops}

As the internet has penetrated into consumers' lives, they have increasingly moved towards online shopping, and as a result most charities launched their online shops to revolutionise the traditional way of retailing. Charities such as Oxfam, British Heart Foundation, Sue Ryder, and CLIC Sargent have both their own online shop and eBay shop. According to the research conducted by the Charity Retail Association in 2011, more than half $(56 \%)$ of all charity shops are selling items online, 94 per cent of charities using eBay and 31 per cent of charities selling through their own websites (Barrett, 2012). Despite the growth in online sales, most charity shops are still not at the level of commercial retailers in selling goods on the internet (Charity Financials, 2011). On a similar note, the charity retail sector has been struggling to adapt to the online marketplace (Paget \& Birdwell, 2013; Institute of Fundraising, 2017). The reason is a lack of resources including both material and managerial. This study can only deal with the managerial aspect of the problem. Therefore, it is essential to study online charity shops in order to help charities to attract more customers, which in turn enables charities to ensure better value from donations (Carmichael, 2016).

There are various studies on charity related topics within the context of charitable giving (Teah et al., 2014; Opoku, 2013; Kottasz, 2004), charity shop donors (Mitchell et al., 2009), charity shop volunteers (Whithear, 1999), charity shop managers (Goodall, 2000; Broadbridge \& Parsons, 2003; Parsons, 2004b; Parsons \& Broadbridge, 2007), charity shoppers (Parsons, 2000; Mitchell \& Montgomery, 2010; Montgomery \& Mitchell, 2014), charity retailing (Parsons, 2002; 2004a; Liu et al., 2014) and online donations (Bennett, 2009). From a consumer perspective, however, there is no research into online charity shops in the literature. A single research study (Goatman \& Lewis, 2007) investigating the use of internet technology by charities has been encountered, but it focuses on the organisational perspective, with the purpose of examining the attitudes of charities towards their own website use. The reason why online charity shops are missing in the existing literature might be that online charity shops are relatively a new phenomenon. For instance, the British Heart Foundation started selling online via their eBay shop in 2006 (British Heart Foundation, 2016), and Oxfam launched the first online charity shop in 2007 (Oxfam, 2017). Therefore, this paper draws attention to the importance of online charity shops as an emerging and promising practice for charities.

In conclusion, considering the previous studies on charities, it can be inferred that there is no such study investigating online charity shops from a marketing perspective. The 
present study, therefore, aims to understand charity shop customers' acceptance of online charity shops, in particular the factors that influence their intention to use online charity shops. In line with the research aim, charity shop customers do not have to have experience with online charity shops. Moreover, this paper does not make any distinction between charities' own online shop and eBay shop; both are considered as online charity shops. Ultimately, the findings of this study are expected to help charities to develop their online shops based on charity shop customers' needs and tastes.

\section{Behavioural Intention}

The study of behavioural intention of new technologies is one of the major concerns of technology adoption models. This study, therefore, investigates the behavioural intention of charity shop customers rather than actual behaviour. Behavioural intention is defined as the degree to which an individual is prompt to perform certain behaviour (Davis, 1989). Behavioural intention is the only dependent variable in this study and refers to the intention to use online charity shops. The UTAUT2 model was deemed appropriate to understand the factors (i.e. performance expectancy, effort expectancy, social influence, facilitating conditions, and hedonic motivation) influencing the charity shop customers' intention to use online charity shops.

\section{Extended Unified Theory of Acceptance and Use of Technology}

Over the decades, various models and theories have been proposed in order to understand the factors that affect the adoption and use of technology, including the Diffusion of Innovations (DOI) by Rogers (1962); the Theory of Reasoned Action (TRA) by Fishbein and Ajzen (1975); the Theory of Planned Behaviour (TPB) by Ajzen (1991); the Technology Acceptance Model (TAM) by Davis (1989); the Extended Technology Acceptance Model (TAM2) by Venkatesh and Davis (2000); the Unified Theory of Acceptance and Use of Technology (UTAUT) Venkatesh et al. (2003), the Online Shopping Acceptance Model (OSAM) by Zhou et al. (2007), and the Extended Unified Theory of Acceptance and Use of Technology (UTAUT2) by Venkatesh et al. (2012).

The Technology Acceptance Model (TAM) developed by Davis (1989) is one of the most influential models used to explain information technology system adoption behaviour (Park et al., 2007). Despite its several limitations, TAM has been one of the most widely used models because of its simplicity (King \& He, 2006). According to Bagozzi (2007), TAM is a remarkable model with its parsimony; however, it is not reasonable to explain technology use intention and behaviour with a simple model in many different contexts. Furthermore, TAM underestimates the affective aspects of user's behavioural intention as it only focuses on user's cognition (Venkatesh \& Davis, 2000).

The prior model of UTAUT incorporates four key constructs (i.e. performance expectancy, effort expectancy, social influence, and facilitating conditions) to explain users' technology adoption behaviour in organisational context (Venkatesh et al., 2003). Thereafter, Venkatesh et al. (2012) tailored the model to the context of consumer acceptance and use of a technology by integrating new constructs (i.e. hedonic motivation, price value, and habit) into UTAUT. Individual differences (i.e. age, gender, and experience) were also hypothesised to moderate their effect on behavioural intention and technology use in UTAUT2 (Venkatesh et al., 2012). In their research, mobile internet technology was studied in a consumer context in Hong Kong, and it was suggested to adapt UTAUT2 to different countries with different technologies. This study investigates charity shop customers' acceptance of online charity shops and the factors influencing their intention to use online charity shops. Therefore, the UTAUT2 model was deemed appropriate as the approach of this study draws upon the consumer perspective in UK context. All the independent variables of UTAUT2, namely 
performance expectancy, effort expectancy, social influence, facilitating conditions, hedonic motivation, price value, and habit, will be discussed in accordance with the relevant literature.

\section{Performance expectancy}

Performance expectancy is defined as "the degree to which using a technology will provide benefits to consumers in performing certain activities" (Venkatesh et al., 2012, p. 159). It is an important construct for behavioural intention in the UTAUT2 model, and corresponds to perceived usefulness in TAM and relative advantage in Diffusion of Innovations (Venkatesh et al., 2003). The research conducted by Venkatesh et al. (2012) and Tandon et al. (2016) found that performance expectancy is positively associated with consumers' behavioural intentions and technology use. On the contrary, Sareen and Jain (2014) argue that there is no significant relationship between performance expectancy and behavioural intention. In this study, therefore, the hypothesis was developed to investigate the influence of performance expectancy on behavioural intention.

H1. Performance expectancy positively influences the intention to use online charity shops.

\section{Effort expectancy}

Effort expectancy refers to "the degree of ease associated with consumers' use of technology" (Venkatesh et al., 2012, p. 159). It is similar to ease of use in TAM and one of the most important determinants to predict the behavioural intention in technology use (Davis, 1989; Thompson et al., 1991). In the study of Sareen and Jain (2014), effort expectancy was an influential factor to the customer's intention to purchase online. However, Lian and Yen (2014) and Escobar-Rodríguez and Carvajal-Trujillo (2013) found that there is no significant impact of effort expectancy on the online purchase intention. In this study, the hypothesis was developed to investigate the influence of effort expectancy on behavioural intention.

H2. Effort expectancy positively influences the intention to use online charity shops.

\section{Social influence}

Social influence is defined as "the extent to which consumers perceive that important others (e.g., family and friends) believe they should use a particular technology" (Venkatesh et al., 2012, p. 159). It corresponds to social norm in TRA and TPB, and it has been proved that social influence has a significant impact on shaping technology users' intention and behaviours. For instance, Rogers (2010) advocates that the users' adoption of technology is influenced by the social factors beyond individuals' thoughts. Moreover, Venkatesh et al. (2012) and $\mathrm{Lu}$ et al. (2005) support that social influence has an impact on behavioural intentions of individuals. On the other hand, Chiu and Wang (2008) argue that social influence has no significant impact on behavioural intention. In this study, the hypothesis was developed to investigate the influence of social influence on behavioural intention.

H3. Social influence positively influences the intention to use online charity shops.

\section{Facilitating conditions}

Facilitating conditions refer to "consumers' perceptions of the resources and support available to perform a behavior" (Venkatesh et al., 2012, p. 159). Some studies reported that facilitating conditions has an important influence on behavioural intention (EscobarRodríguez \& Carvajal-Trujillo, 2013; Sareen \& Jain, 2014). However, Baptista and Oliveira (2015) found that facilitating conditions was found to have no significant impact on the behavioural intention. In this study, the hypothesis was developed to investigate the influence of facilitating conditions on behavioural intention. 

shops.

H4. Facilitating conditions positively influence the intention to use online charity

\section{Hedonic motivation}

Hedonic motivation is "the fun or pleasure derived from using a technology" (Venkatesh et al., 2012, p. 161). According to Huang and Kao (2015) and Childers et al. (2001), hedonic motivation is an important determinant of consumers' technology acceptance. However, Oliveira et al. (2016) found that it is not a significant predictor of the behavioural intention. In this study, the hypothesis was developed to investigate the influence of hedonic motivation on behavioural intention.

H5. Hedonic motivation positively influences the intention to use online charity shops.

\section{Price value}

Price value is defined as "the cognitive tradeoff between perceptions of quality and sacrifice results in perceptions of value" (Dodds, et al., 1991, p. 308). In the online shopping context, price value does not appear in UTAUT2 since it does not incur any additional costs to online shoppers (Pascual-Miguel, et al., 2015). In the same vein, the use of online charity shops is at no charge; therefore, the construct price value was dropped.

\section{Habit}

Habit is defined as "the extent to which people tend to perform behaviours automatically because of learning" (Venkatesh, et al., 2012, p. 161). As online charity shopping is a relatively new phenomenon, it is assumed that few people are accustomed to online charity shops. Thus, in this study, the intention to use online charity shops is the final construct rather than use behaviour, and accordingly the construct habit was dropped.

\section{Individual differences}

In UTAUT2, individual differences (i.e. age, gender, and experience) were also hypothesised to moderate their effect on behavioural intention. Gender and age appeared as moderating variables of all relationships in UTAUT2, and experience was conceptualised as three levels based on passage of time in their longitudinal study (Venkatesh et al., 2003; 2012). As the present study only investigates charity shop customers' intention to use online charity shops at a single time point, the moderating effect of experience is not relevant in this research. Here, in this study, general questions in terms of age, gender, and experience were asked in order to profile participants only.

\section{Theoretical Framework}

The present study employs the Extended Unified Theory of Acceptance and Use of Technology (UTAUT2) since it is meant for the understanding consumers' behavioural intention to use a new technology. As the model is relatively new in the literature, it needs to be studied in different contexts (Venkatesh et al., 2012). Additionally, online charity shops are relatively new phenomena. Therefore, UTAUT2 was deemed appropriate to identify the factors influencing charity shop customers' intention to use online charity shops in the UK context. The figure given below demonstrates the relationships of all variables in UTAUT2. 


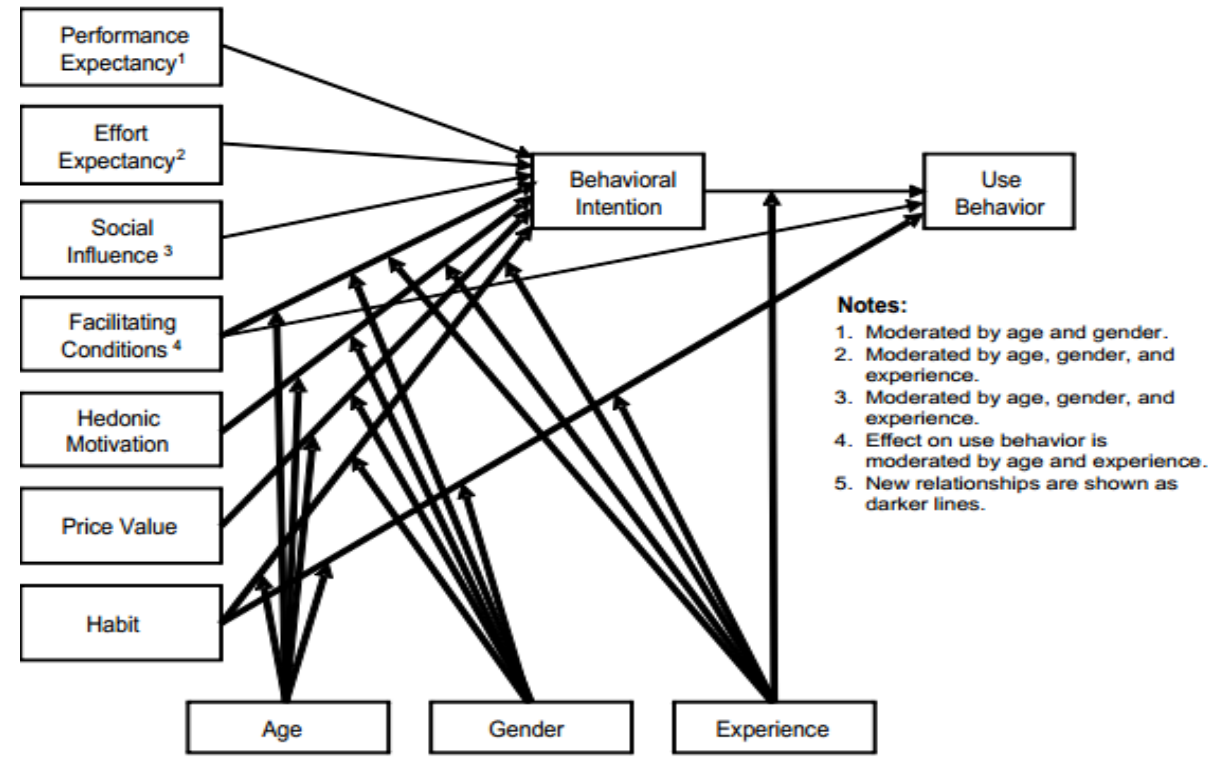

Figure 1: The UTAUT2 Model (Venkatesh et al., 2012, p. 160)

\section{Research Model}

This study employs the Extended Unified UTAUT2 model by excluding price value and habit constructs as well as the moderating effect of age, gender, and experience. As this research only examines charity shop customers' behavioural intention, use behaviour was also excluded from the research model. The proposed research model is demonstrated in Figure 2.

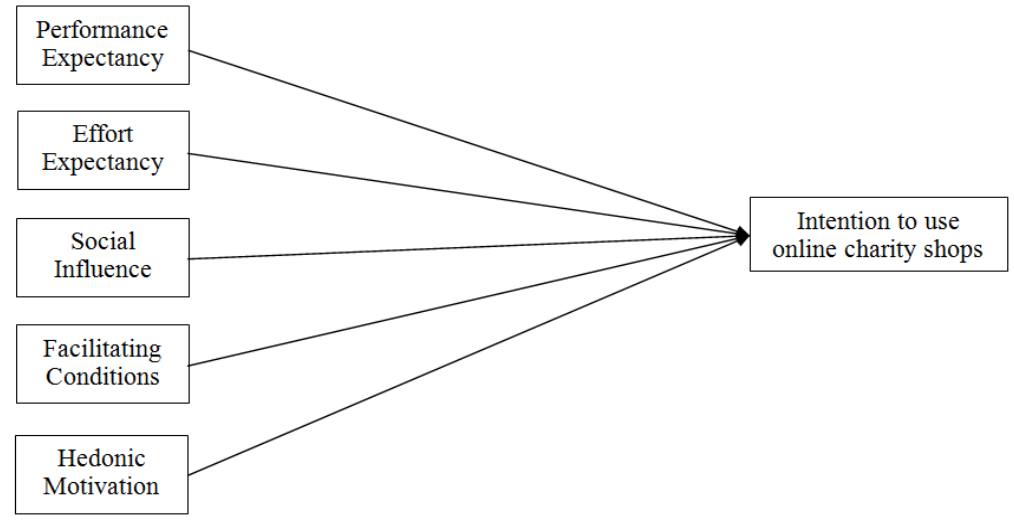

Figure 2: Research Model

\section{Research Methodology}

Saunders et al. (2012, p. 5) define the term research as "something that people undertake in order to find out things in a systematic way, thereby increasing their knowledge". In this definition, they emphasise the two phrases which are 'systematic way' and 'to find out things', and accordingly business and management research is defined as 'undertaking systematic research to find out things about business and management' (Saunders et al., 2012, p. 6). That is, they underline that the research should have a clear purpose and be based on logical relationships providing a justification of the methods used to gather the data.

The main purpose of this study is to identify the factors influencing charity shop customers' intention to use online charity shops. After defining the research purpose, a research strategy should be established since it provides "overall direction of the research including the process by which the research is conducted" (Remenyi et al., 1998, p. 44). To be 
able to find the right direction, it is essential to understand the research philosophy that underpins the research strategy and the methods chosen as part of that strategy (Saunders, et al., 2012). Accordingly, the research onion model (see Figure 3) forms the basis for this chapter to have a good grasp of the entire research process and to provide justifications when tailoring an appropriate research methodology to the present study.

In light of the research onion model, first of all, the research philosophies demonstrated on the outer layer of the onion need to be explained. Secondly, the appropriate research approach is determined in accordance with the research philosophy adopted. The next stage introduces the research design which is concerned with the overall plan for the research (Saunders et al., 2012). In the fourth step, the research strategies are considered, and then the time horizon is identified. Lastly, the centre of the research onion represents the stage at which data collection techniques and data analysis procedures are specified.

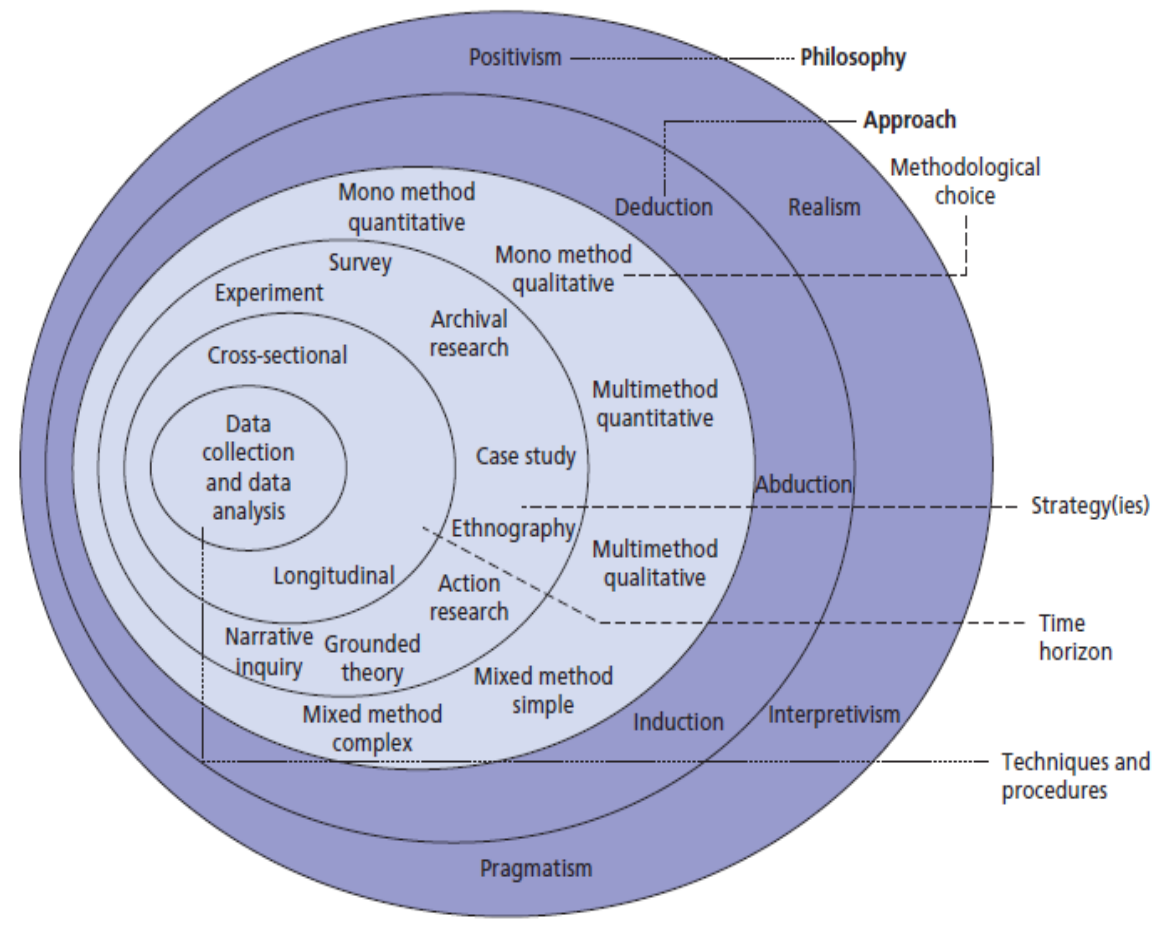

Figure 3: The Research Onion (Saunders et al., 2012, p. 128)

\section{Research Philosophy}

Saunders et al. (2012, p. 127) define research philosophy as "the development of knowledge and the nature of that knowledge", and name two primary means of research philosophy: epistemology and ontology. Ontology and epistemology are two different viewpoints of the research philosophy. Ontology is defined as "a branch of philosophy concerned with articulating the nature and structure of the world" (Wand \& Weber, 1993, p. 220), and includes two contrasting positions, objectivism and subjectivism. Epistemology, on the other hand, is defined as "the branch of philosophy that evaluates competing views of the morality, nature, definition, standards, sources, and functions of knowledge" (Rawwas et al., 2013, p. 525). According to Antwi and Hamza (2015), there are two broad epistemological positions: positivism and interpretivism.

An appropriate research philosophy for the present study should be decided to peel away the first layer of the onion. The epistemological sense of this research is based on positivism, as this study is designed for data collection through an online survey to evaluate hypotheses based on an existing theory, UTAUT2. For some researchers, positivism 
represents superficial data collection whereas for others, it depicts "a philosophical position that can be discerned in research". (Bryman \& Bell, 2011, p. 15). The ontological stance of this research is rooted in the objectivist research philosophy, which is basically free from control of the social factors and the researcher's influence.

\section{Research Approach}

Saunders et al. (2012) suggest three research approaches: deduction (moving from theory to data), induction (moving from data to theory), and abduction (moving back and forth). Since the focus is on using data to test theory, a deductive approach is adopted in this study to understand relationships between variables, that is, the relationships between the particular UTAUT2 constructs and the intention to use online charity shops.

\section{Research Methodology}

Quantitative research is generally associated with positivism whereas qualitative research is linked with an interpretive philosophy (Saunders et al., 2012). Quantitative and qualitative methods have their own research strategies and each has significant differences related to the role of theory, epistemological and ontological concerns (Bryman and Bell, 2007). Quantitative research is defined as "the collection of data that involves larger, more representative respondent samples and the numerical calculation of results" (Wiid \& Diggines, 2009, p. 86). Quantitative research usually seeks a causative relationship between particular variables whereas qualitative research usually studies the meaning of social phenomena (Feilzer, 2010). In this study, therefore, quantitative research is deemed appropriate since the research aim is to investigate the relationship among variables by testing hypotheses. However, there are some problems with quantitative research such as inflexibility and lack of depth (Bryman \& Bell, 2011).

\section{Research Strategy}

Research strategy is defined as "a plan of how a researcher will go about answering her or his research question" (Saunders et al., 2012, p. 173). In this regard, the research strategy creates a bridge between the philosophy and the methods of research (Denzin \& Lincoln, 2005). There are several strategies such as experiment, survey, case study, ethnography, etc. Experiment and survey are linked to quantitative research design while ethnography is linked to qualitative research design. Case study can be used in qualitative or quantitative research, or a mixed design (Saunders et al., 2012). A survey strategy is often linked to a deductive research approach and widely used in business and management research, and produces quantitative data that can be analysed empirically (Saunders et al., 2012). They also state that the survey strategy is an economical way of collecting large amount of data as it is less expensive and time saving and also can be used to evaluate certain relationships between variables. In this study, therefore, survey strategy is deemed appropriate to test hypotheses to understand the relationships between certain UTAUT2 constructs and the intention to use online charity shops.

\section{Time Horizons}

Choosing a time horizon also has an important role in designing the research. In the research onion, two types of time horizons are demonstrated: the cross-sectional and the longitudinal. According to Saunders et al. (2012), the cross-sectional time horizon, or the 'snapshot' time horizon, refers to the study of a specific phenomenon at a specific time. They also emphasise that cross-sectional studies generally use the survey strategy; however, they may also utilise qualitative methods. The longitudinal research refers to the collection of data repeatedly over time. In line with the aim of this study, cross-sectional study approach is 
preferred over the longitudinal study approach. In other words, this study is based on surveys conducted over a short period of time.

\section{Data Collection and Analysis}

The centre of the research onion is data collection and analysis. Data collection techniques and analytic procedures can be determined based on the methodological approach adopted, and contributes to the study's overall reliability and validity (Saunders et al., 2012). The present study employs quantitative research approach with a survey strategy. As the onion is peeled away, the research strategy is being integrated.

\section{Data collection technique}

In qualitative research, data is mostly collected by interview, focus group discussion and observation whereas in quantitative research by questionnaire and psychological tests (Antwi \& Hamza, 2015). As the present study employs quantitative research approach with a survey strategy, the data collection technique should be decided accordingly. Questionnaires are deemed more suitable for descriptive or explanatory research rather than exploratory research. (Saunders, et al., 2012). Since this study investigates the effects of defined key factors of the UTAUT2 model on charity shop customers' intention to use online charity shops, an explanatory research approach was adopted. The present study, therefore, uses a questionnaire to collect data, in particular, self-administered questionnaires. Saunders et al. (2012) indicates that such questionnaires performed by the participants are generally administered online (internet-mediated questionnaires). Accordingly, as this study deals with the intention to use online charity shops, an online survey was developed using Typeform which is a service company allowing people to build online forms. After creating the online questionnaire, the survey link was shared on the internet, particularly on social media channels such as Facebook and Twitter.

\section{Sampling technique}

Bryman and Bell (2011) define a sample as "the segment of the population that is selected for the investigation" (p. 176). It is a subset of the population and the method of selection is based on a probability or non-probability approach. The probability sampling is the most appropriate in quantitative research since respondents are selected randomly, in turn, it enables the researcher to have a heterogeneous sample which is more representative than a non-random sample, and the findings from the sample can be generalised to the population (Bryman \& Bell, 2011). On the other hand, non-probability sampling techniques are preferred when the resources are limited or the sample frame cannot be specified (Saunders, et al., 2012). The target population of this research consists of people who shop at charity shops on high streets across the UK, both male and female aged 18 and above. The population of charity shop customers in the UK could not been figured out, thus, the present study employs a non-probability sampling approach. The matter of sample size in non-probability sampling is ambiguous, except for quota sampling, so there are no rules contrary to probability sampling (Saunders et al., 2012). In non-probability sampling, accordingly, some problems are likely to occur such as lack of representation of the entire population.

There are several non-probability sampling techniques such as quota sampling, snowball sampling, purposive sampling, self-selection sampling, and convenience sampling. In this study, self-selection sampling technique was employed, which allows the researchers to publicise their requirement for cases by inviting them to take part and to obtain data from the respondents (Saunders et al., 2012). The UK's charity shops were listed based on the internet search, and then social media accounts of certain charities were identified. Oxfam GB, British Heart Foundation, Cancer Research UK, Macmillan Cancer Support, Barnardo's, 
Sue Ryder, Thames Hospice, and Save the Children UK were found on Facebook and Twitter. Accordingly, the survey link was posted on their official Facebook page in order to invite charity shoppers to participate in the online survey. At the same time, the survey link was tweeted to random people who follow their verified Twitter page. The link was shared as a hyperlink on both Facebook and Twitter so that the participants were automatically directed to the questionnaire by clicking on it. People who volunteered to participate in the survey were expected to be a charity shop customer. In case people who follow charities page might only be donors, it was clearly mentioned in the introductory part in which the participants were informed about the study before starting the questionnaire. According to Peterson (2000), screening, or filter, questions are necessary in order to understand if the participant is meant for the research. Therefore, at the beginning of the questionnaire, one screening question was asked to make sure if they do shopping in charity shops on high streets across the UK. It was important to clarify this point because the scope of this paper is limited to charity shop customers in the UK.

\section{Instrument}

A questionnaire was developed for the research based on the UTAUT2 constructs (see Appendix C). The constructs and sources of the questionnaire items are demonstrated in Table 1. The items for performance expectancy ( 3 items), effort expectancy (4 items), facilitating conditions (4 items), hedonic motivation (3 items), and behavioural intention (3 items) were adapted from Venkatesh et al. (2012), and the items for social influence (3 items) were adapted from Wei et al. (2009) and Venkatesh et al. (2012). Each item was tailored to the context of online charity shop and was measured on a seven-point Likert scale, ranging from 1 (strongly disagree) to 7 (strongly agree). Moreover, two demographic questions were asked in the first part of the questionnaire, including age and gender. Gender was measured using a nominal scale and age was grouped into five categories. Three questions about the experience with online charity shops were also included in the first part as well as one filter question. In total, the questionnaire consists of 27 questions.

Table 1: Sources of the questionnaire items

\begin{tabular}{lll}
\hline Constructs & No. of items & Sources \\
\hline Performance Expectancy (PE) & 3 & Venkatesh et al. (2012) \\
Effort Expectancy (EE) & 4 & Venkatesh et al. (2012) \\
Social Influence (SI) & 3 & Venkatesh et al. (2012) and Wei et al. (2009) \\
Facilitating Conditions (FC) & 4 & Venkatesh et al. (2012) \\
Hedonic Motivations (HM) & 3 & Venkatesh et al. (2012) \\
Behavioural Intention (BI) & 3 & Venkatesh et al. (2012) \\
\hline
\end{tabular}

\section{Pilot study}

Saunders et al. (2012) suggest that before conducting the main study, the questionnaire needs to be pilot tested in order to assess the questions' validity and reliability of the data. The present study employs a validated instrument, the UTAUT2 model. Thus, prior to the main study, a pilot study was conducted with 10 charity shop customers to determine the reliability of the UTAUT2 instrument regarding their Cronbach's Alpha value. The result of the pilot study confirmed that it was reliable (see Table 2). Moreover, they were asked to give feedback about the wording of the questions, layout of the survey and time required to finish 
the survey. Based on their feedback, the background colour of online survey was changed, and the time required for completion of the questionnaire was determined 5-10 minutes.

Reliability is defined as "the extent to which your data collection techniques or analysis procedures will yield consistent findings" (Saunders et al., 2012, p. 156). Cronbach's Alpha value ranging from 0 to 1 is one of the most widely used measures of internal consistency. Thus, a pilot study was conducted with 10 charity shop customers to determine the internal consistency of the UTAUT2 items regarding their Cronbach's Alpha value. It is assumed that a value greater than 0.9 represents excellent reliability, between 0.9 and 0.8 is good, and between 0.8 and 0.7 is acceptable (Cronbach \& Shavelson, 2004). According to the results in Table 1, the Cronbach's Alpha value of the items varies between 0.772 and 0.921 . The value of each item fulfils the requirement of over $0.70(\alpha>.70)$ as proposed by Cronbach and Shavelson (2004), therefore, all variables can be accepted and used for data collection.

Table 2: Reliability analysis of the pilot study

\begin{tabular}{llll}
\hline Variables & No. of items & Cronbach's Alpha & Remarks \\
\hline Performance Expectancy & 3 & 0.772 & Acceptable \\
Effort Expectancy & 4 & 0.846 & Good \\
Social Influence & 3 & 0.921 & Excellent \\
Facilitating Conditions & 4 & 0.877 & Good \\
Hedonic Motivations & 3 & 0.738 & Acceptable \\
Intention to Use Online Charity Shops & 3 & 0.841 & Good \\
\hline
\end{tabular}

\section{Data analysis technique}

The data collection process lasted 14 days, from September 1 until September 14 in 2017. The data obtained from the pilot test was not used for the data analysis of the main study. Excluding 7 invalid responses, 152 responses were received. Those 7 responses were discarded because they did not match the inclusion criteria (shopping at charity shops on high streets across the UK). Therefore, the responses of the participants whose answer is 'no' for the screening question were deemed invalid.

The relationship between variables can be assessed using correlation and regression (Saunders et al., 2012). In this study, therefore, these techniques were utilised in line with the research hypotheses. A software package, Statistical Package for Social Sciences (SPSS), was also decided as a tool for analysing data.

\section{Research ethics}

According to Saunders et al. (2012), research ethics is about the way defining the research topic, designing the research, collecting data, processing and analysing data, and writing up the research findings morally and responsibly. The present study, therefore, was conducted considering the ethical concerns. Moreover, Collis and Hussey (2009) argue that participants must be voluntary and informed about the research as well as their confidentiality. Accordingly, an introductory part in which the participants were informed about the study was entailed to the beginning of the online survey. The issue of voluntary participation and confidentially was addressed, and it was also clarified that the results will be used only for academic research. 


\section{Results and Analysis}

\section{Descriptive Statistics}

\section{Characteristics of the sample}

In the first section of the survey questionnaire, basic demographic questions regarding participants' age and gender, and general questions about their experience with high street charity shops took place. In the second part, the participants were asked about their experience with online charity shops. Demographic information of the participants and experience related questions were collected in order to see the individual differences.

Table 3: Demographic characteristics of the respondents

\begin{tabular}{llll}
\hline Item & Characteristics & Frequency & Percentage $(\%)$ \\
\hline Gender & Male & 65 & 42.8 \\
& Female & 87 & 57.2 \\
& Other & 0 & 0.0 \\
Age & $18-25$ & 34 & 22.4 \\
& $26-35$ & 48 & 31.6 \\
& $36-45$ & 37 & 24.3 \\
& $46-55$ & 12 & 7.9 \\
& $>55$ & 21 & 13.8 \\
\hline
\end{tabular}

Table 4: Behavioural characteristics of the respondents

\begin{tabular}{llll}
\hline Item & Characteristics & Frequency & Percentage (\%) \\
\hline $\begin{array}{l}\text { Frequency of shopping at high street } \\
\text { charity shops }\end{array}$ & More than once a week & 23 & 15.1 \\
& Once a week & 58 & 38.2 \\
& Once every other week & 36 & 23.7 \\
& Once a month & 24 & 15.8 \\
& Less than once a month & 11 & 7.2 \\
\hline $\begin{array}{l}\text { Prior experience in using online charity } \\
\text { shops }\end{array}$ & Yes & 49 & 32.2 \\
\hline $\begin{array}{l}\text { Length of experience in using online } \\
\text { charity shops }\end{array}$ & Less than 1 year & 29 & 67.8 \\
\hline & 1 to 3 years & 8 & 59.2 \\
\hline Frequency of using online charity shops & Nore than 3 years & 12 & 16.3 \\
\hline & Seldom & 0 & 24.5 \\
\hline
\end{tabular}




\begin{tabular}{llcc}
\hline & Sometimes & 14 & 28.6 \\
& Often & 7 & 14.3 \\
& Very often & 0 & 0.0 \\
& Always & 0 & 0.0 \\
\hline
\end{tabular}

The demographic and behavioural characteristics of 152 respondents collected from the survey questionnaire are summarised in Table 3 and Table 4. In addition, demographic profile of the respondents is demonstrated in Figure 4. The results were retrieved from frequency and descriptive analysis of demography and experience related questions. Accordingly, most of the respondents are female with 57.2 per cent, and the majority of the respondents fall between the age of 26 and 35 with 31.6 per cent. Moreover, 38.2 per cent of the respondents shops at high street charity shops once a week whereas 7.2 per cent does shopping less than once a month. Regarding their experience with online charity shops, only 32.2 per cent of the respondents have purchased a product from a charity's online shop. Among those, 59.2 per cent has less than one year experience with online charity shops, and 57.1 per cent seldom uses online charity shops.

In the last section of the questionnaire, it is intended to identify the factors influencing charity shop customers' intention to use online charity shops. The UTAUT2 items were analysed at the interval measurement scale. Accordingly, the participants were requested to rate each statement related to online charity shops on a seven-point Likert scale ranging from 1 (strongly disagree) to 7 (strongly agree). To analyse Likert scale items, particular data analysis procedures such as Pearson correlation, t-test, ANOVA, and regression are recommended, besides descriptive statistics including the mean for central tendency and standard deviations for variability (Boone \& Boone, 2012). In Table 4, therefore, the descriptive statistics of the UTAUT2 constructs are demonstrated. The mean values of the constructs vary between 3.325 and 5.680, which implies that the majority of the respondents opted for agree, neutral or disagree. As shown in the table, the highest value for standard deviation is 1.388 .

Table 5: Descriptive statistics of the constructs

\begin{tabular}{lllllll}
\hline Variables & Constructs & N & Minimum & Maximum & Mean & Std. Deviation \\
\hline IV1 & PE & 152 & 1.00 & 7.00 & 4.738 & 1.388 \\
IV2 & EE & 152 & 1.00 & 7.00 & 5.483 & 1.078 \\
IV3 & SI & 152 & 1.00 & 7.00 & 3.325 & 1.104 \\
IV4 & FC & 152 & 1.00 & 7.00 & 5.680 & 1.030 \\
IV5 & HM & 152 & 1.00 & 7.00 & 5.098 & 1.373 \\
DV & BI & 152 & 1.00 & 7.00 & 5.496 & 1.302 \\
\hline
\end{tabular}

\section{Normality test}

In Table 6, the normality results of all UTAUT2 items are presented. The values between -2 and +2 are considered acceptable for skewness and kurtosis (Gravetter \& Wallnau, 2014). As shown in the table, the skewness and kurtosis values of each UTAUT2 item are within the acceptable range, thus, the variables are deemed normally distributed. 
Table 6: Normality statistics

\begin{tabular}{|c|c|c|c|}
\hline Constructs & Items & Skewness & Kurtosis \\
\hline \multirow{3}{*}{ PE } & PE1 & 0.489 & -0.882 \\
\hline & PE2 & -0.614 & 0.941 \\
\hline & PE3 & -0.082 & -0.186 \\
\hline \multirow{4}{*}{ EE } & EE1 & -0.223 & -0.018 \\
\hline & EE2 & 0.082 & -0.186 \\
\hline & EE3 & -0.614 & 0.942 \\
\hline & EE4 & -0.409 & 1.099 \\
\hline \multirow{3}{*}{ SI } & SI1 & -0.446 & 0.175 \\
\hline & SI2 & -0.463 & 0.291 \\
\hline & SI3 & 0.114 & 0.256 \\
\hline \multirow{4}{*}{ FC } & FC1 & -0.345 & 0.468 \\
\hline & FC2 & -0.383 & 0.828 \\
\hline & $\mathrm{FC} 3$ & -0.464 & 1.352 \\
\hline & FC4 & -0.636 & 0.617 \\
\hline \multirow{3}{*}{ HM } & HM1 & -0.409 & 1.098 \\
\hline & HM2 & 0.210 & -0.047 \\
\hline & HM3 & -0.349 & 0.267 \\
\hline \multirow{3}{*}{ BI } & BI1 & -0.209 & 0.754 \\
\hline & BI2 & -0.347 & 0.668 \\
\hline & BI3 & -0.183 & 0.343 \\
\hline
\end{tabular}

\section{Hypotheses Testing}

In survey research, the focus is mainly on the strength of the relationship between variables. If variables are normally distributed Pearson's correlation coefficient is used instead of Spearman's. (Pallant, 2016). Accordingly, Pearson correlation was deemed appropriate in this case since the variables are normally distributed (see Table 6). In addition, regression analysis was employed to investigate the relationship among variables in line with the research hypotheses.

\section{Pearson correlation}

The correlation coefficient varies between -1 and +1 , and the sign of the coefficient determines the direction of the relationship (Pallant, 2016). To interpret the size of correlation coefficients, the guideline proposed by Hinkle et al. (2003) is explained below; 


$$
\begin{aligned}
& r=.90 \text { to } 1.00(-.90 \text { to }-1.00)=>\text { Very high positive (negative) correlation } \\
& r=.70 \text { to } .90(-.70 \text { to }-.90)=>\text { High positive (negative) correlation } \\
& r=.50 \text { to } .70(-.50 \text { to }-.70)=>\text { Moderate positive (negative) correlation } \\
& r=.30 \text { to } .50(-.30 \text { to }-.50) \Rightarrow>\text { Low positive (negative) correlation } \\
& r=.00 \text { to } .30(-.00 \text { to }-.30)=>\text { Negligible correlation }
\end{aligned}
$$

Table 7: Pearson's correlation coefficient

$\begin{array}{lll} & \text { Pearson Correlation } & \\ \text { Hypotheses } & (* * \mathrm{p}<0.01) & \text { Interpretation } \\ & (2 \text {-tailed }) & \end{array}$

H1: Performance expectancy positively influences the intention to use online charity shops.

$0.548 * * \quad$ Moderate

H2. Effort expectancy positively influences the intention to use online charity shops.

H3. Social influence positively influences the intention to use online charity shops.

Low

H4. Facilitating conditions positively influence the intention to use online charity shops.

H5. Hedonic motivation positively influences the intention to use online charity shops.

** Correlation is significant at the 0.01 level (2-tailed).

Based on the guideline, Pearson correlation results were interpreted and presented in Table 7. The relationships determined by correlation coefficients imply associations, not causal relationships. As the correlation coefficient values ranges from 0.451 to 0.710 , it can be inferred that there is a positive relationship between the variables, and the relationships are statistically significant $(\mathrm{p}<0.01)$. Facilitating conditions $(\mathrm{FC})$ has a strong significant relationship with behavioural intention (BI), while performance expectancy (PE), effort expectancy (EE), and hedonic motivation (HM) have a moderate relationship. On the other hand, social influence (SI) has a weak relationship with behavioural intention.

\section{Regression analysis}

To estimate relationship among variables, simple linear regression was conducted in line with the research hypotheses. shops.

H1. Performance expectancy positively influences the intention to use online charity

Regarding Hypothesis $1(\mathrm{H} 1), \mathrm{R}$-squared in the model summary $\left(\mathrm{R}^{2}=.300\right)$ implies that $30 \%$ of the total variation in the dependent variable (behavioural intention) is explained by the independent variable (performance expectancy). 
Model Summary

\begin{tabular}{|l|c|r|r|r|}
\hline Model & R & R Square & \multicolumn{1}{c|}{$\begin{array}{c}\text { Adjusted R } \\
\text { Square }\end{array}$} & $\begin{array}{c}\text { Std. Error of } \\
\text { the Estimate }\end{array}$ \\
\hline 1 & $.548^{\mathrm{a}}$ & .300 & .298 & .79309 \\
\hline
\end{tabular}

a. Predictors: (Constant), performance expectancy

The model has an $\mathrm{F}$ ratio of 147.239 and a p-value of $.000(\mathrm{p}<0.05)$ which indicates that the relationship between performance expectancy and behavioural intention is significant.

ANOVA $^{\mathrm{a}}$

\begin{tabular}{|ll|r|r|r|r|r|}
\hline Model & & \multicolumn{1}{c|}{$\begin{array}{c}\text { Sum of } \\
\text { Squares }\end{array}$} & \multicolumn{1}{c|}{$\mathrm{df}$} & Mean Square & \multicolumn{1}{c|}{$\mathrm{F}$} & \multicolumn{1}{c|}{ Sig. } \\
\hline 1 & Regression & 92.613 & 1 & 92.613 & 147.239 & $.000^{\mathrm{b}}$ \\
& Residual & 215.745 & 150 & .629 & & \\
& Total & 308.358 & 151 & & & \\
\hline
\end{tabular}

a. Dependent Variable: behavioural intention

b. Predictors: (Constant), performance expectancy

Further, the table of coefficients shows that performance expectancy has an influence on behavioural intention $(\beta=.548, \mathrm{t}=12.134, \mathrm{p}=.000)$. Therefore, $\mathrm{H} 1$ is accepted.

Coefficients $^{a}$

\begin{tabular}{|c|c|c|c|c|c|c|}
\hline \multirow{2}{*}{\multicolumn{2}{|c|}{ Model }} & \multicolumn{2}{|c|}{ Unstandardized Coefficients } & \multirow{2}{*}{$\begin{array}{c}\begin{array}{c}\text { Standardized } \\
\text { Coefficients }\end{array} \\
\text { Beta }\end{array}$} & \multirow[b]{2}{*}{$\mathrm{t}$} & \multirow[b]{2}{*}{ Sig. } \\
\hline & & $B$ & Std. Error & & & \\
\hline & (Constant) & 1.291 & .175 & & 7.392 & .000 \\
\hline & performance expectancy & .599 & .049 & .548 & 12.134 & .000 \\
\hline
\end{tabular}

a. Dependent Variable: behavioural intention

H2. Effort expectancy positively influences the intention to use online charity shops.

Regarding Hypothesis $2(\mathrm{H} 2), \mathrm{R}$-squared in the model summary $\left(\mathrm{R}^{2}=.438\right)$ implies that $43.8 \%$ of the total variation in the dependent variable (behavioural intention) is explained by effort expectancy.

Model Summary

\begin{tabular}{|l|r|r|r|r|}
\hline Model & $\mathrm{R}$ & $\mathrm{R}$ Square & $\begin{array}{c}\text { Adjusted R } \\
\text { Square }\end{array}$ & $\begin{array}{c}\text { Std. Error of } \\
\text { the Estimate }\end{array}$ \\
\hline 1 & $.662^{\mathrm{a}}$ & .438 & .436 & .65099 \\
\hline
\end{tabular}

a. Predictors: (Constant), effort expectancy

The model has an $\mathrm{F}$ ratio of 266.899 and a p-value of $.000(\mathrm{p}<0.05)$ which indicates that the relationship between effort expectancy and behavioural intention is significant. 
ANOVA $^{\mathrm{a}}$

\begin{tabular}{|ll|r|r|r|r|c|}
\hline \multicolumn{1}{|l|}{} & \multicolumn{1}{c|}{$\begin{array}{c}\text { Sum of } \\
\text { Squares }\end{array}$} & df & Mean Square & \multicolumn{1}{c|}{$\mathrm{F}$} & Sig. \\
\hline 1 & Regression & 113.108 & 1 & 113.108 & 266.899 & $.000^{\mathrm{b}}$ \\
& Residual & 145.359 & 150 & .424 & & \\
& Total & 258.467 & 151 & & & \\
\hline
\end{tabular}

a. Dependent Variable: behavioural intention

b. Predictors: (Constant), effort expectancy

Further, the table of coefficients shows that effort expectancy has an influence on behavioural intention $(\beta=.662, t=16.337, p=.000)$. Thus, it is concluded that $\mathrm{H} 2$ is accepted.

Coefficients $^{\mathrm{a}}$

\begin{tabular}{|c|c|c|c|c|c|c|}
\hline \multirow{2}{*}{\multicolumn{2}{|c|}{ Model }} & \multicolumn{2}{|c|}{ Unstandardized Coefficients } & \multirow{2}{*}{$\begin{array}{c}\text { Standardized } \\
\text { Coefficients } \\
\text { Beta }\end{array}$} & \multirow[b]{2}{*}{$t$} & \multirow[b]{2}{*}{ Sig. } \\
\hline & & $\mathrm{B}$ & Std. Error & & & \\
\hline \multirow[t]{2}{*}{1} & (Constant) & .950 & .156 & & 6.087 & .000 \\
\hline & effort expectancy & .706 & .043 & .662 & 16.337 & .000 \\
\hline
\end{tabular}

a. Dependent Variable: behavioural intention

H3. Social influence positively influences the intention to use online charity shops.

Regarding Hypothesis $3(\mathrm{H} 3)$, R-squared in the model summary $\left(\mathrm{R}^{2}=.204\right)$ implies that $20.4 \%$ of the total variation in the dependent variable (behavioural intention) is explained by social influence.

Model Summary

\begin{tabular}{|l|l|r|r|r|}
\hline Model & $\mathrm{R}$ & R Square & \multicolumn{1}{c|}{$\begin{array}{c}\text { Adjusted R } \\
\text { Square }\end{array}$} & $\begin{array}{c}\text { Std. Error of } \\
\text { the Estimate }\end{array}$ \\
\hline 1 & $.451^{\mathrm{a}}$ & .204 & .201 & .72542 \\
\hline
\end{tabular}

a. Predictors: (Constant), social influence

The model has an $F$ ratio of 87.723 and a p-value of $.000(p<0.05)$ which indicates that the relationship between social influence and behavioural intention is significant.

ANOVA $^{\mathrm{a}}$

\begin{tabular}{|ll|r|r|r|r|r|}
\hline Model & & \multicolumn{1}{c|}{$\begin{array}{c}\text { Sum of } \\
\text { Squares }\end{array}$} & df & Mean Square & \multicolumn{1}{c|}{$\mathrm{F}$} & \multicolumn{1}{c|}{ Sig. } \\
\hline 1 & Regression & 46.163 & 1 & 46.163 & 87.723 & $.000^{\mathrm{b}}$ \\
& Residual & 180.499 & 150 & .526 & & \\
& Total & 226.662 & 151 & & & \\
\hline
\end{tabular}

a. Dependent Variable: behavioural intention

b. Predictors: (Constant), social influence

Further, the table of coefficients shows that social influence has an influence on behavioural intention $(\beta=.451, \mathrm{t}=9.366, \mathrm{p}=.000)$. Thus, it is concluded that $\mathrm{H} 3$ is accepted. 
Coefficients $^{\mathrm{a}}$

\begin{tabular}{|ll|r|r|r|r|r|}
\hline \multirow{2}{*}{ Model } & \multicolumn{2}{|c|}{} & \multicolumn{2}{|c|}{$\begin{array}{c}\text { Standardized } \\
\text { Unstandardized Coefficients }\end{array}$} & \\
\cline { 3 - 5 } & & \multicolumn{1}{|c|}{$\mathrm{B}$} & Std. Error & \multicolumn{1}{c|}{ Beta } & \multicolumn{1}{c|}{$\mathrm{t}$} & \multicolumn{1}{c|}{ Sig. } \\
\hline 1 & (Constant) & 2.519 & .113 & & 22.208 & .000 \\
& social influence & .333 & .036 & .451 & 9.366 & .000 \\
\hline
\end{tabular}

a. Dependent Variable: behavioural intention shops.

H4. Facilitating conditions positively influence the intention to use online charity

Regarding Hypothesis $4(\mathrm{H} 4), \mathrm{R}$-squared in the model summary $\left(\mathrm{R}^{2}=.504\right)$ implies that $50.4 \%$ of the total variation in the dependent variable (behavioural intention) is explained by facilitation conditions.

Model Summary

\begin{tabular}{|l|c|r|r|r|}
\hline Model & R & R Square & \multicolumn{1}{c|}{$\begin{array}{c}\text { Adjusted R } \\
\text { Square }\end{array}$} & $\begin{array}{c}\text { Std. Error of } \\
\text { the Estimate }\end{array}$ \\
\hline 1 & $.710^{\mathrm{a}}$ & .504 & .502 & .57262 \\
\hline
\end{tabular}

a. Predictors: (Constant), facilitating conditions

The model has an $F$ ratio of 348.280 and a p-value of $.000(\mathrm{p}<0.05)$ which indicates that the relationship between facilitating conditions and behavioural intention is significant.

ANOVA $^{\mathrm{a}}$

\begin{tabular}{|rl|r|r|r|r|r|}
\hline Model & & \multicolumn{1}{c|}{$\begin{array}{c}\text { Sum of } \\
\text { Squares }\end{array}$} & df & Mean Square & \multicolumn{1}{c|}{ F } & Sig. \\
\hline 1 & Regression & 114.197 & 1 & 114.197 & 348.280 & $.000^{\mathrm{b}}$ \\
& Residual & 112.466 & 150 & .328 & & \\
& Total & 226.662 & 151 & & & \\
\hline
\end{tabular}

a. Dependent Variable: behavioural intention

b. Predictors: (Constant), facilitating conditions

Further, the table of coefficients shows that facilitating conditions has an influence on behavioural intention $(\beta=.710, t=18.662, p=.000)$. Thus, it is concluded that $\mathrm{H} 4$ is accepted.

Coefficients $^{a}$

\begin{tabular}{|c|c|c|c|c|c|c|}
\hline \multirow{2}{*}{\multicolumn{2}{|c|}{ Model }} & \multicolumn{2}{|c|}{ Unstandardized Coefficients } & \multirow{2}{*}{$\begin{array}{c}\begin{array}{c}\text { Standardized } \\
\text { Coefficients }\end{array} \\
\text { Beta }\end{array}$} & \multirow[b]{2}{*}{$\mathrm{t}$} & \multirow[b]{2}{*}{ Sig. } \\
\hline & & $B$ & Std. Error & & & \\
\hline \multirow[t]{2}{*}{1} & (Constant) & -.017 & .192 & & -.091 & .928 \\
\hline & facilitating conditions & .902 & .048 & .710 & 18.662 & .000 \\
\hline
\end{tabular}

a. Dependent Variable: behavioural intention

H5. Hedonic motivation positively influences the intention to use online charity shops.

Regarding Hypothesis 5 (H5), R-squared in the model summary $\left(\mathrm{R}^{2}=.504\right)$ implies that $50.4 \%$ of the total variation in the dependent variable (behavioural intention) is explained by hedonic motivation. 
Model Summary

\begin{tabular}{|l|c|r|r|r|}
\hline Model & $\mathrm{R}$ & R Square & \multicolumn{1}{c|}{$\begin{array}{c}\text { Adjusted R } \\
\text { Square }\end{array}$} & $\begin{array}{c}\text { Std. Error of } \\
\text { the Estimate }\end{array}$ \\
\hline 1 & $.668^{\mathrm{a}}$ & .446 & .445 & .60488 \\
\hline
\end{tabular}

a. Predictors: (Constant), hedonic motivation

The model also has an $\mathrm{F}$ ratio of 276.494 and a p-value of $.000(\mathrm{p}<0.05)$ which indicates that the relationship between hedonic motivation and behavioural intention is significant.

ANOVA $^{a}$

\begin{tabular}{|ll|r|r|r|r|r|}
\hline \multicolumn{2}{|l|}{ Model } & \multicolumn{1}{c|}{$\begin{array}{c}\text { Sum of } \\
\text { Squares }\end{array}$} & \multicolumn{1}{c|}{$\mathrm{df}$} & Mean Square & \multicolumn{1}{c|}{$\mathrm{F}$} & Sig. \\
\hline 1 & Regression & 101.164 & 1 & 101.164 & 276.494 & $.000^{\mathrm{b}}$ \\
& Residual & 125.498 & 150 & .366 & & \\
& Total & 226.662 & 151 & & & \\
\hline
\end{tabular}

a. Dependent Variable: behavioural intention

b. Predictors: (Constant), hedonic motivation

Further, the table of coefficients shows that facilitating conditions has an influence on behavioural intention $(\beta=.668 \mathrm{t}=16.628, \mathrm{p}=.000)$. Thus, it is concluded that $\mathrm{H} 5$ is accepted.

Coefficients $^{\mathrm{a}}$

\begin{tabular}{|c|c|c|c|c|c|c|}
\hline \multirow{2}{*}{\multicolumn{2}{|c|}{ Model }} & \multicolumn{2}{|c|}{ Unstandardized Coefficients } & \multirow{2}{*}{$\begin{array}{c}\begin{array}{c}\text { Standardized } \\
\text { Coefficients }\end{array} \\
\text { Beta } \\
\end{array}$} & \multirow[b]{2}{*}{$\mathrm{t}$} & \multirow[b]{2}{*}{ Sig. } \\
\hline & & B & Std. Error & & & \\
\hline \multirow[t]{2}{*}{1} & (Constant) & .810 & .166 & & 4.882 & .000 \\
\hline & hedonic motivation & .790 & .048 & .668 & 16.628 & .000 \\
\hline
\end{tabular}

a. Dependent Variable: behavioural intention

In conclusion, all hypotheses are accepted. However, each variable has an influence on the intention to use online charity shops in dissimilar level. In the following chapter, the results are discussed in comparison with previous studies.

\section{Discussion}

All hypotheses developed for this research were accepted based on $p$-value $(p<.05)$ resulting from regression analysis. The results revealed performance expectancy significantly affects charity shop customers' intention to use online charity shops. This complies with the results of the study conducted by Venkatesh et al. (2012) and Tandon et al. (2016) arguing that performance expectancy is positively associated with consumers' behavioural intentions. However, it contradicts the research findings of Sareen and Jain (2014) who found that there is no significant relationship between performance expectancy and behavioural intention. Charity shop customers believe that online charity shops are useful in their daily life and increases their productivity in accomplishing shopping tasks more quickly.

Regarding Hypothesis 2, the results showed that effort expectancy positively influences the intention to use online charity shops. This supports the findings from the research by Sareen and Jain (2014), indicating that effort expectancy was an influential factor to the customer's intention to purchase online. On the other hand, it contradicts the study of 
Lian and Yen (2014) and Escobar-Rodríguez and Carvajal-Trujillo (2013) who concluded that there is no significant impact of effort expectancy on the online purchase intention. The results imply that charity shop customers find online charity shops easy to use and understandable. They also think that they can become skilful at using them. Accordingly, it can be inferred that an online charity shop can help charity shop customers accomplish shopping tasks faster since they find it easy to use.

The study also found that social influence affects the intention to use online charity shops significantly. This is in agreement with the study of Rogers (2010) who advocates that the users' adoption of technology is influenced by the social factors beyond individuals' thoughts, and the study of Venkatesh et al. (2012) and Lu et al. (2005) supporting that social influence has an impact on behavioural intentions of individuals. However, it differs from the research findings presented by Chiu and Wang (2008) who argue that social influence has no significant impact on behavioural intention. It can be inferred that charity shop customers tend to be influenced by word-of-mouth based on the recommendations of their family and friends.

According to the research findings, it was found that facilitating conditions positively influences the intention to use online charity shops. This aligns with the findings of EscobarRodríguez and Carvajal-Trujillo (2013) and Sareen and Jain (2014) asserting that facilitating conditions has an important influence on behavioural intention. However, it does not comply with the study of Baptista and Oliveira (2015) arguing that facilitating conditions has no significant impact on the behavioural intention. Based on the findings, it is concluded that charity shop customers are sure that they have necessary resources, knowledge and technologies to be able to use online charity shops.

In Hypothesis 5, it was supported that hedonic motivation affects charity shop customers' intention to use online charity shops. This is in agreement with the study of Huang and Kao (2015) and Childers et al. (2001), while contradicting with Oliveira et al. (2016) who assert that hedonic motivation is not a significant predictor of the behavioural intention. In this study, findings showed that charity shop customers would find using online charity shops fun and entertaining. Accordingly, it can be said that their intention is driven by the enjoyable and pleasurable aspects of the online charity shops.

\section{Conclusions and Recommendations}

\section{Marketing Implications}

The findings of this study revealed that several factors influence charity shop customers' intention to use online charity shops. From a managerial perspective, specific marketing implications are recommended to charitable organisations to help them to formulate successful strategies for their online charity shops. For instance, facilitating conditions is the most significant factor in behavioural intention (intention to use online charity shops); therefore, charitable organisations should more concentrate on this. They may offer a mobile application which allows their customers to shop online. Additionally, hedonic motivation is another important factor influencing the intention. Besides developing applications, marketers should also consider the fun and entertaining aspects of the online charity shops, either on the website or on the application.

Considering the significant influence of effort expectancy on behavioural intention, marketers should pay attention to the design of online charity shops. They should be userfriendly, that is easy to use and navigate. In addition, marketers should emphasise on the consumer perspective considering the online charity shops' functionality since performance expectancy is another important predictor of behavioural intention. Furthermore, marketers 
are advised to promote online charity shops on social media sites such as Facebook, Twitter and Instagram as social influence also is a significant factor in behavioural intention.

\section{Limitations and Recommendations}

The present study has several limitations which can be considered as an opportunity for future studies. First of all, the dependent variable of this research is intention to use online charity shops which tends to be measured subjectively as it investigates charity shop customers' prospective behaviour. However, it was recommended to study use behaviour (Venkatesh, et al., 2012). Secondly, the moderating effect of gender, age and experience, which exists in the original study of UTAUT2, was not taken into account in this study. Future research should consider individual differences to see their effect on relationships between variables. Moreover, this study only focuses on charity sector; therefore, future research should extend the scope of this study in various contexts.

Another limitation of this study is about sampling. This research employed a nonprobability sampling which has some drawbacks such as lack of representation of the entire population. Besides, this study was conducted with only a small group of sample due to the time and budget constraints. Additionally, the sample is composed of disproportionately more women than men $(57.2 \%$ versus $42.8 \%)$. However, it can be understandable since women are more likely to have ever purchased an item from a charity shop than men (Charities Aid Foundation, 2016).

\section{Conclusion}

The key factors that influence charity shop customers' intention to use online charity shops have been identified employing the UTAUT2 model. Accordingly, the research findings revealed that facilitating conditions (FC) has the most significant influence on behavioural intention, followed by hedonic motivation (HM), effort expectancy (EE), performance expectancy (PE), and social influence (SI). Overall, this paper intends to contribute to the literature by shedding new light on the factors that determine charity shop customers' intention to use online charity shops, and in turn, to draw particular managerial and marketing implications that enable charities to devise successful strategies in order to attract more charity shoppers to their online shops.

\section{References}

Ajzen, I. (1991). The theory of planned behavior. Organizational Behavior and Human Decision Processes, 50(2), 179-211.

Antwi, S. K., \& Hamza, K. (2015). Qualitative and quantitative research paradigms in business research: A philosophical reflection. European Journal of Business and Management, 7(3), 217-225.

Bagozzi, R. P. (2007). The legacy of the technology acceptance model and a proposal for a paradigm shift. Journal of the Association for Information Systems, 8(4), 244-254.

Baptista, G., \& Oliveira, T. (2015). Understanding mobile banking: The unified theory of acceptance and use of technology combined with cultural moderators. Computers in Human Behavior, 50, 418-430.

Bardhi, F. (2003). Thrill of the hunt: Thrift shopping for pleasure. Advances in Consumer Research, 30(30), 375-376.

Barrett, C. (2012). Charity shops turn to Ebay to boost sales. Retrieved July 8, 2017, from https://www.ft.com/content/5ed94b12-58d4-11e1-b9c6-00144feabdc0 
Bennett, R. (2009). Impulsive donation decisions during online browsing of charity websites. Journal of Consumer Behaviour, 8(2-3), 116-134.

Boone, H. N., \& Boone, D. A. (2012). Analyzing likert data. Journal of Extension, 50(2), 1-5.

British Heart Foundation. (2016, September 5). Annual Report and Accounts 2016. Retrieved July 27, 2017, from https://www.bhf.org.uk/publications/about-bhf/annual-report-andaccounts-2016

Broadbridge, A., \& Parsons, E. (2003). UK charity retailing: Managing in a newly professionalised sector. Journal of Marketing Management, 19(7-8), 729-748.

Bryman, A., \& Bell, E. (2011). Business research methods (3rd ed.). Oxford: Oxford University Press.

Carmichael, Z. (2016). Charity shops: Is the future online? Retrieved July 15, 2017, from https://nfpsynergy.net/blog/charity-shops-future-online

Charities Aid Foundation. (2016, July). Charity Street II: The value of charity to British households. Retrieved July 18, 2017, from https://www.cafonline.org/docs/defaultsource/about-us-publications/160704_caf_charity_street_report_web.pdf

Charity Financials. (2011). Charity shops increase online retail sales. Retrieved August 1, 2017, from http://www.charityfinancials.com/charity-financials-insider/charity-shopsincrease-online-retail-sales-1070.html

Charity Retail Association. (2015). Charity shops. Retrieved July 5, 2017, from https://www.charityretail.org.uk/charity-shops/

Charity Retail Association. (2017). General Election 2017: A manifesto for the UK's charity shops. Retrieved July 23, 2017, from https://www.charityretail.org.uk/wpcontent/uploads/2017/05/CRA-General-Election-Manifesto-2017.pdf

Childers, T. L., Carr, C. L., Peck, J., \& Carson, S. (2001). Hedonic and Utilitarian Motivations for Online Retail Shopping Behavior. Journal of Retailing, 77(4), 511535 .

Chiu, C., \& Wang, E. T. (2008). Understanding Web-based learning continuance intention: The role of subjective task value. Information \& Management, 45(3), 194-201.

Collis, J., \& Hussey, R. (2009). Business Research: A Practical Guide for Undergraduate \& Postgraduate Students (3rd ed.). London: Palgrave Macmillan.

Cronbach, L. J., \& Shavelson, R. J. (2004). My Current Thoughts on Coefficient Alpha and Successor Procedures. Educational and Psychological Measurement, 64(3), 391-418.

Davis, F. D. (1989). Perceived usefulness, perceived ease-of-use, and user acceptance of information technology. MIS Quarterly, 13(3), 319-340.

Denzin, N. K., \& Lincoln, Y. S. (2005). The Sage Handbook of Qualitative Research (3rd ed.). London: Sage.

Dodds, W. B., Monroe, K. B., \& Grewal, D. (1991). Effects of Price, Brand, and Store Information on Buyers' Product Evaluations. Journal of Marketing Research, 28(3), 307-319.

Escobar-Rodríguez, T., \& Carvajal-Trujillo, E. (2013). Online drivers of consumer purchase of website airline tickets. Journal of Air Transport Management, 32, 58-64. 
Feilzer, M. Y. (2010). Doing mixed methods research pragmatically: Implications for the rediscovery of pragmatism as a research paradigm. Journal of Mixed Methods Research, 4(1), 6-16.

Fishbein, M., \& Ajzen, I. (1975). Belief, attitude, intention and behavior: an introduction to theory and research. Reading, MA: Addison-Wesley.

Goatman, A. K., \& Lewis, B. R. (2007). Charity E-volution? An evaluation of the attitudes of UK charities towards website adoption and use. International journal of nonprofit and voluntary sector marketing, 12(1), 33-46.

Goodall, R. (2000). Charity shops in sectoral contexts: The view from the boardroom. International Journal of Nonprofitand Voluntary Sector Marketing, 5(2), 105-112.

Gravetter, F., \& Wallnau, L. (2014). Essentials of statistics for the behavioral sciences (8th ed.). Belmont, CA: Wadsworth.

Hinkle, D. E., Wiersma, W., \& Jurs, S. G. (2003). Applied Statistics for the Behavioral Sciences (5th ed.). Boston, Mass: Houghton Mifflin.

Horne, S. (2000). The charity shop: Purpose and change. International Journal of Nonprofitand Voluntary Sector Marketing, 5(2), 113-124.

Horne, S., \& Maddrell, A. (2002). Charity Shops: Retailing, Consumption and Society. London: Routledge.

Huang, C., \& Kao, Y. (2015). UTAUT2 based predictions of factors influencing the technology acceptance of phablets by DNP. Mathematical Problems in Engineering, $1-23$.

Institute of Fundraising. (2017, February 9). Charity Today 2017. Retrieved July 18, 2017, from http://www.institute-of-fundraising.org.uk/library/charity-today-2017/

King, W. R., \& He, J. (2006). A meta-analysis of the technology acceptance model. Information \& Management, 43(6), 740-755.

Kottasz, R. (2004). How should charitable organisations motivate young professionals to give philanthropically? International Journal of Nonprofit and Voluntary Sector Marketing, 9(1), 9-27.

Lian, J., \& Yen, D. (2014). Online shopping drivers and barriers for older adults: Age and gender differences. Computers in Human Behavior, 37, 133-143.

Liu, G., Eng, T., \& Sekhon, Y. K. (2014). Managing Branding and Legitimacy: A Study of Charity Retail Sector. Nonprofit and Voluntary Sector Quarterly, 43(4), 629-651.

Lu, H., Hsu, C., \& Hsu, H. (2005). An empirical study of the effect of perceived risk upon intention to use online applications. Information Management \& Computer Security, 13(2), 106-120.

Mintel. (2017, April 28). Contactless payments: the future of charitable donations? . Retrieved July 25, 2017, from http://academic.mintel.com/display/830887/?highlight

Mitchell, M., \& Montgomery, R. D. (2010). An Examination of Thrift Store Shoppers. The Marketing Management Journal, 20(2), 94-107.

Mitchell, M., Montgomery, R. D., \& Rauch, D. (2009). Toward an understanding of thrift store donors. International Journal of Nonprofit and Voluntary Sector Marketing, 14(3), 255-269. 
Montgomery, R. D., \& Mitchell, M. (2014). Examining the demographic profiles of thrift store donors and thrift store shoppers. Atlantic Marketing Journal, 3(1), 1-13.

Oliveira, T., Thomas, M., Baptista, G., \& Campos, F. (2016). Mobile payment: Understanding the determinants of customer adoption and intention to recommend the technology. Computers in Human Behavior, 61, 404-414.

Opoku, R. A. (2013). Examining the motivational factors behind charitable giving among young people in a prominent Islamic country: Motivational factors behind charitable giving. International Journal of Nonprofit and Voluntary Sector Marketing, 18(3), 172-186.

Oxfam. (2017). Bumper Christmas for Oxfam shops: sales at five-year high. Retrieved July 6, 2017, from http://www.oxfam.org.uk/media-centre/press-releases/2017/01/bumperchristmas-for-oxfam-shops-sales-at-five-year-high

Paget, A., \& Birdwell, J. (2013, November 25). Giving Something Back. Retrieved July 17, 2017 from https://www.demos.co.uk/files/DEMOS_givingsomethingbackREPORT.pdf?1385343 669

Pallant, J. (2016). SPSS survival manual: a step by step guide to data analysis using IBM SPSS (6th ed.). Maidenhead: McGraw-Hill Education.

Park, J., Yang, S., \& Lehto, X. (2007). Adoption of mobile technologies for Chinese consumers. Journal of Electronic Commerce Research, 8(3), 196-206.

Parsons, E. (2002). Charity retail: past, present and future. International Journal of Retail \& Distribution Management, 30(12), 586-594.

Parsons, E. (2004a). Charity retailing in the UK: a typology. Journal of Retailing and Consumer Services, 11(1), 31-40.

Parsons, E. (2004b). Charity shop managers in the UK: becoming more professional? Journal of Retailing and Consumer Services, 11(5), 259-268.

Parsons, E., \& Broadbridge, A. (2007). Charity, retail or care? Gender and managerialism in the charity retail sector. Women in Management Review, 22(7), 552-567.

Parsons, L. (2000). New goods, old records and second-hand suits: Charity shopping in South-West England. International Journal of Nonprofit and Voluntary Sector Marketing, 5(2), 141-151.

Pascual-Miguel, F., Agudo-Peregrina, A., \& Chaparro-Pelaez, J. (2015). Influences of gender and product type on online purchasing. Journal of Business Research, 68(7), 15501556.

Peterson, R. A. (2000). Constructing Effective Questionnaires. Thousands Oaks, CA: Sage.

Rawwas, M., Arjoon, S., \& Sidani, Y. (2013). An Introduction of Epistemology to Business Ethics: A Study of Marketing Middle-Managers. Journal of Business Ethics, 117(3), 525-539.

Remenyi, D., Williams, B., Money, A., \& Swartz, E. (1998). Doing Research in Business and Management. An Introduction to Process and Method. London: Sage.

Rogers, E. M. (1962). Diffusion of innovations. New York: Free Press of Glencoe.

Rogers, E. M. (2010). Diffusion of Innovations (4th ed.). New York: Simon and Schuster. 
Sareen, M., \& Jain, A. (2014). The role of social influence and consumer's effort expectancy in online shopping: an empirical study in India. International Journal of Management Research and Business Strategy, 3(1), 138-158.

Saunders, M., Lewis, P., \& Thornhill, A. (2012). Research Methods for Business Students (6th ed.). London: Pearson.

Seager, C. (2014). Charity shops: what's in store? Retrieved July 22, 2017, from https://www.theguardian.com/voluntary-sector-network/2014/mar/22/what-is-thefuture-charity-shops

Tandon, U., Kiran, R., \& Sah, A. (2016). Understanding Online Shopping Adoption in India: Unified Theory of Acceptance and Use of Technology 2 (UTAUT2) with Perceived Risk Application. Service Science, 8(4), 420-437.

Teah, M., Lwin, M., \& Cheah, I. (2014). Moderating role of religious beliefs on attitudes towards charities and motivation to donate. Asia Pacific Journal of Marketing and Logistics, 26(5), 738-760.

Thompson, R. L., Higgins, C. A., \& Howell, J. M. (1991). Personal computing: toward a conceptual model of utilization. MIS Quarterly, 15(1), 125-143.

Venkatesh, V., \& Davis, F. D. (2000). A Theoretical Extension of the Technology Acceptance Model: Four Longitudinal Field Studies. Management Science, 46(2), 186-204.

Venkatesh, V., Morris, M. G., Davis, G. B., \& Davis, F. D. (2003). User Acceptance of Information Technology: Toward a Unified View. MIS Quarterly, 27(3), 425-478.

Venkatesh, V., Thong, J., \& Xu, X. (2012). Consumer acceptance and use of information technology: Extending the unified theory of acceptance and use of technology. MIS Quarterly, 36(1), 157-178.

Wand, Y., \& Weber, R. (1993). On the ontological expressiveness of information systems analysis and design grammars. Journal of Information Systems, 3(4), 217-237.

Wei, T. T., Marthandan, G., Chong, A. Y., Ooi, K. B., \& Arumugam, S. (2009). What drives Malaysian m-commerce adoption? An empirical analysis. Industrial Management \& Data Systems, 109(3), 370-388.

Whithear, R. (1999). Charity shop volunteers: a case for 'tender loving care'. International Journal of Nonprofit and Voluntary Sector Marketing, 4(2), 107-120.

Wiid, J., \& Diggines, C. (2009). Marketing Research. Cape Town: Juta and Company Ltd.

Zhou, L., Dai, L., \& Zhang, D. (2007). Online Shopping Acceptance Model: A Critical Survey of Consumer Factors in Online Shopping. Journal of Electronic Commerce Research, 8(1), 41-62. 